\title{
The effectiveness of a family counseling program in improving the meaning of life among deaf blind children
}

\section{Eman Mohamed Ibrahim Ahmed (PhD)}

Associate Professor of Casework High Institute of Social Work, Alexandria 


\section{Abstract:}

The present study aims to examine the effectiveness of a family counseling program in improving the meaning of life for deaf-blind children. The sample of the study consisted of the families of 10 deafblind children in the age groups from 9 to 12 years. The study employed a measure of improving the meaning of life for deaf-blind children, and the results confirmed the existence of highly statistically significant differences between the measurements of the pre and post means on the scale of the meaning of life, for the experimental group. Deaf-blind children scored highest in all the three aspects; purpose of life, life satisfaction, adaptability, and; there fore, an indication of the effectiveness of the family counseling program in improving the meaning of life for deaf-blind children. The study also indicated that there are differences between the means of pre and post measurement for deaf blind children, males and females, on the meaning of life scale, in favor of female children, in terms of satisfaction with life alone. The study was concluded with recommendations for deaf-blind children.

Key words: a family counseling program, the meaning of life, deaf blind children.

\section{Introduction:}

The group of deaf-blind people is one of the recently classified group as an independent group of handicapped, according to the World Health Organization's (WHO) report(World Health Organization [WHO], 2017). Also, the international classification of the functional performance, disability and health issued by the Nations International Children's Emergency Fund [UNICEF], indicated that deaf blind people are classified among the sensory disabilities group ( UNICEF, 2014).

The NCDB stated that U.S.A has 9384 babies, children and youth who have been defined as having both hearing and visual disabilities, a much smaller number compared to the previous years. It also stated that almost $90 \%$ of the children and youth in the national census of deaf blind children have more than one disability, in addition to deafness and blindness (Wolford, 2016).

The data of Helen Keller International Center suggested that there is about one million deaf blind adults in USA (Helen Keller National Center for Deaf-Blind Youths \& Adults (HKNC), 2015). 
Deafness/ blindness is a comprehensive term that admits that a deaf blind person have different levels of disability and faces unique daily life problems(Gaspar, Rebelo \& Dijk, 2017).

Nordic staff training center confirmed that the hearing and visual disabilities should be considered as a unique disability that requires a special approach for communication and other means to keep up with the daily life requirements (Nordic staff training center [NUD], 2005) and that this group of people is one of the most vulnerable ones of the community(Simcock \& Manthorpe, 2013). Lack of early identification of deafness and blindness, in early childhood, is the main reason for the delay and inadequacy of intervention and education necessary for early development and learning for those children (Herbster, 2015), (Muller, 2006) and (Purvis \& Schalock, 2014).

Deaf blind people face many problems in various fields such as communication; access to information, orientation and movement, in addition to their suffering from isolation, withdrawal, self- arousal, lack of communication and social interaction and lack of ability to discovering. Vervloed, van Dijk, Knoors and van Dijk (2006), Jaiswal, Aldersey, Wittich, Mirza and Finlayson (2018), all agree on this.

The issues of puberty are different, for these are common feelings such as fear, hardships in daily tasks and issues in keeping the relationships (MacDonnall, Crudden, LeJeune \& Stewerson, 2014). Many studies of the deaf blind people were executed such as Sukontharungsee, Bourquin and Poonpit (2006) and Al-jabr (2015)that showed the poor services provided for the deaf blind people, inadequacy of rehabilitation services, lack of positive social support for them, the severe lack in trained teachers who should deal with them, lack of sufficient educational programs. The study of Manga and Masuku (2020)also indicated that the teachers of the deaf blind students face certain challenges in terms of the educational environment due to their lack of the sufficient knowledge about the deafness and blindness, as well as, the lack of sufficient training in the strategies of communication, teaching and learning and the study of Bruce et al. (2020) held the same view.

The studies emphasized the many challenges facing parents, educators and car- providers of deaf blind children, not the least of those was the child's participation in family and social life. Nevertheless, these challenges were not impossible as many deaf blind people managed to achieve high life quality. The works of Trivette 
and Dunst (2005),Kyzar (2010), Preisler (2005) and Al-Utaiby and Sarttawy (2012)confirmed the significant need for intervention service among deaf blind children and their families, as the intervention providers can offer the children motivation and enable them to develop interactive behaviors.

The results of the studies of Turner, Baldwin, Kleinert and Farmer Kearns (2000), Wolsey (2017),Janssen, Riksen-Walraven and van Dijk (2002)showed the importance of selecting the curriculum suitable for the student; whether in terms of its content or modification to fit the abilities, potentials and needs of persons of multiple disability. This is in addition to the role of the supportive educational environment to acquire social and academic skills within normal conditions through designing supportive programs to enhance the social, academic and psychological aspects for the child.

The research of Frederickson and Turner (2003),Tsuchiya and Sugai (2001), Gaspar et al. (2017),Sayed (2015), (Ezzat, 2010)and Abdul Hafith (2008) emphasized the importance of providing programs for developing the social and daily life skills among deaf blind people, as well as, the necessity of supporting their independence, education, protection against isolation, enhancing their communication through learning and using the touch sign language by all relevant people, and the health, educational and social policies to provide equal chances in terms of sex and age. Several studies confirmed the importance of focusing on improving the life quality of deaf blind children including the work of Dammeyer (2012)andWhite (2014). On the other hand, the studies of Kyzar, Brady, Summers and Turnbull (2018) and Roy, McVillly and Crisp (2019) emphasized the importance of partnership between the family and professionals as the main supporter for the deaf blind children's families, as well as, the necessity to focus on family interaction, parental well- being and the social well- being.

The researcher found on the basis of the previous studies that the role played by the family in their deaf blind children's life is the main role in helping them face the challenges of their disability and develop their ability to improve the meaning of their life(Frankl, 1990, p. 48). This confirms that the meaning of life is the main motivation that helps human survive the worst conditions, overcome self, having positive attitude towards life and optimistic attitudes towards the future through finding out the positive aspects, potentials and abilities within themselves instead of focusing on their negative sides of personality. 
Therefore, the researcher emphasizes the significance of the supporting role of family in improving the meaning of life of their deaf blind children; thus, the current study examines the effectiveness of a family counseling program in improving the meaning of life among deaf blind children.

Study Importance: This lies in the fact that deaf blind people receive very small research focus on the international level. Additionally, based on previous research, there is need for intervention with deaf blind children and their families and the effectiveness of relevant treatment in improving and developing character, as well as, treating many disorders such as anxiety, depression, fear of death, and lack of purpose in life.

The study objectives: 1 - To verify the effectiveness of the family counseling program in improving the meaning of life among deaf-blind children in terms of (purpose of life - satisfaction with life ability to adapt). 2- Identifying the differences between male and female deaf blind children in terms of meaningful life scale.

Study hypotheses: There are statistically significant differences between the mean of measurements before and after measuring the meaning of life in deaf-blind children who prefer the later measurement in terms of (purpose of life - satisfaction with life ability to adapt) and 2. there are statistically significant differences between the average pre and post measures of male and female deaf blind children in terms of the life of meaning scale.

\section{The study concepts:}

1- Deaf blind definition: The international law definition of deaf blind people states that these are the people of sight measure of $2 / 200$ or less in the better eye after using eyeglasses, or those of sight range of $20^{\circ}$ or less in and those who have sever loss of hearing that leads to their lack of ability to understand speech(Ingraham, 2007, p. 8).

The National Consortium on Deaf-Blindness, (Deaf-Blindness, 2018)stated in their definition of deaf blind people that these are the individuals who have both hearing and vision impairments that cause them severe communication problems and both developmental and educational needs that cannot be satisfied through the only deaf or the only blind programs(Deaf-Blindness, 2018; McCormick, 2015). 
The researcher defines deaf blind children in the current study as: children in late childhoods who were diagnosed with deafness and partial blindness and who receive the proper services with their families in special communities qualified for this service.

2- Counseling Program definition: The family counseling for exceptional children's families is defined as: "assisting relationship between a training specialist and the parents of an exceptional child seeking to reach a better understanding of their interests, problems and feelings. It is an educational process that focuses on motivating and encouraging personal development that enables the counsel to help parents acquire, develop and apply the skills and attitudes necessary to reach a satisfactory resolution of their problems or interests. Counseling helps parents become totally effective in serving their child and to live in harmony as members in a completely compatible family.”(Aly, 2010, p. 19).

Despite educators' interest in the family's participation in educating all children; yet such interest increases in cases of disabled children. The family's participation varies from negative roles that are almost limited to receiving information and advice to very effective and influential roles that in some cases reach setting policies, decisions and advising others (Al- Khateeb, 1997).

The researcher defines the counseling program in the current study as: a series of organized and planned counseling sessions in the light of scientific bases, that target deaf blind children's families to improve the meaning of life among their children, through activating the deaf blind family's role to enable their children to set goals in life, feeling of life satisfaction and the ability to accommodate.

3- The concept of "meaning of life":The meaning of life is defined as: "a state sought by a person to give his/ her life a living worthy value and meaning and happens due to satisfaction of their basic motive the need for the meaning."(Frankl, 1982).

It is also defined as: "a group of individual responses reflecting their positive or negative attitudes towards life and its different objectives, aspects and obligations such as education, work or their feeling of importance, value, motive to move positively to achieve them, their ability to take responsibility, self- embracing, selftranscendence among others and general life satisfaction."(Abyadh, 2010). 
It also defined as: "individuals' feeling of the value of life and their positive expectations thereof."(Hamidi, Yetkin \& Yatkin, 2010).

The researcher defines life as the degree of rights a family believes that its deaf blind child is entitled to receive on the scale of meaning of life and it includes indices of: the goal of life, life satisfaction, the ability to accommodate; while the goal of life is "the extent to which the child realizes the purpose and meaning of life, and the thing that makes his life valuable and meaningful", Life satisfaction is "the child's level of satisfaction with his presence in life, self-acceptance, disability and the ability to accept the fate of life." Adaptability is "the child's ability to overcome the difficulties and circumstances of life and accept them without any feeling of despair.

Study's Theories:(Logo Therapy):This is a therapeutic school of human direction that means a spiritually directed through the logo. The logo therapy is defined as: "a series of techniques and activities, inspired from Frankl's principles and basics in his Logo therapy theory, that confirms human's individuality and free will and that human's existence has a meaning and a value. This therapy can enable discovering the strengths and weaknesses, as well as, investing the original power in finding a meaning and goal of life and experiencing the quality of life."(Vector, 2004, p. 14).

Logo therapy is a human direction that tackles human morally. Its main objective is understanding the human existence and deepening the awareness thereof; rooting the feeling of freedom and responsibility; counseling the well of meaning that makes life, work, love, suffering and even death of real meaning that enables a person' self- overcoming, positive movement in life, optimistic attitude towards the future, benefiting from previously achieved potentials in forming the present and planning the future through awareness of the positive aspects and the powers owned instead of the negative aspects(Fathy, 2006, p. 53). and Abu Ghazala (2007), Sameer (2007).

The researcher uses logo therapy in this research to enable deaf blind children's families to improve the meaning of life for their children through helping them to set life goals, because without goals life would be meaningless, in addition to, enhancing the feeling of life satisfaction and accommodation with disability. 


\section{Professional intervention program:}

\section{First: counseling program objectives:}

General objective: Improving the meaning of life among deaf blind children through working with their families to help their children set their life goals, increasing the sense of satisfaction and the ability to accommodate with the disability.

\section{Program procedural objectives:}

1. Family participation in setting life goals for their child through positive participation, assuming responsibilities instead of isolation, increasing their abilities to define tasks and achieve them, develop better future plans, develop their abilities to make correct decisions, and continuously search for self - developing and understanding the required time management skill For success.

2. Helping the family for their children to feel satisfied with their lives: through training them to exercise personal responsibilities, meet life needs, practice personal learning, participate in tasks and programs for developing independent living skills, and understand civic responsibilities as a member of society.

3. The family helps its children to adapt to life: by integrating children into the social environment with their families and relatives, increasing their social interaction, and increasing children's sense of optimism and hope in life, confidence, impulse control, self-defense, and knowledge of civil rights. The child should practice religious rituals regularly.

Second: program period: 12 sessions in 12 weeks.

Third: counseling program contexts:

- Targeting context: (the family and deaf blind children): through aiding parents to increase communication and interaction between the deaf blind child and his/ her family, peers and friends and increasing their ability of social interaction, accommodation and setting life goals and achieving life satisfaction.

- Change (performance) context: as people cooperate with the researcher to achieve the objectives of counseling program; these are:1-The deaf blind activities agent in the center as he provided the place for holding the session which provides quietness and confidentiality.2-Social workers of the center.

- Change achieving context: the researcher who counseled and provided the support and guidance to the deaf blind children using 


\begin{tabular}{|lr||}
\hline Egyptian Journal of Social Work (EJSW) & http://ejsw.journals.ekb.eg \\
ISSN: 2356-9204 & Vol 12, Issue 1, June 2021 \\
\hline \hline
\end{tabular}

the therapeutic techniques and approaches of case work (logo therapy).

Forth: stages and steps of counseling program application:

\begin{tabular}{|c|c|}
\hline Aspects & "Counseling program content \\
\hline $\begin{array}{lr}\text { First } & \text { stage: } \\
\text { (building } & \\
\text { counseling } & \\
\text { relationship } & \text { and } \\
\text { setting } & \text { the } \\
\text { problem } & \text { and } \\
\text { objectives) } & \\
(2 \text { weeks) } & \end{array}$ & $\begin{array}{l}\text { - Pre- testing through applying the scale of improving the } \\
\text { meaning of life for deaf blind children through parents. } \\
\text { - Introducing and agreeing with the children's families on the } \\
\text { counseling sessions and their dates and confirming their } \\
\text { confidentiality. } \\
\text { - Forming guiding relationships of understanding, acceptance } \\
\text { and freedom of speech, and clearly stating the objectives of } \\
\text { the mentoring program. } \\
\text { - Setting the basic rules of the counseling meeting with clear } \\
\text { understanding of the problem and encouraging the families } \\
\text { to talk and gradually move along the discussion development } \\
\text { to organize the thoughts' sequence. } \\
\text { Defining the deaf blind children's needs and problems and } \\
\text { their link to their ability to feel the meaning of life and } \\
\text { accommodation therewith. }\end{array}$ \\
\hline 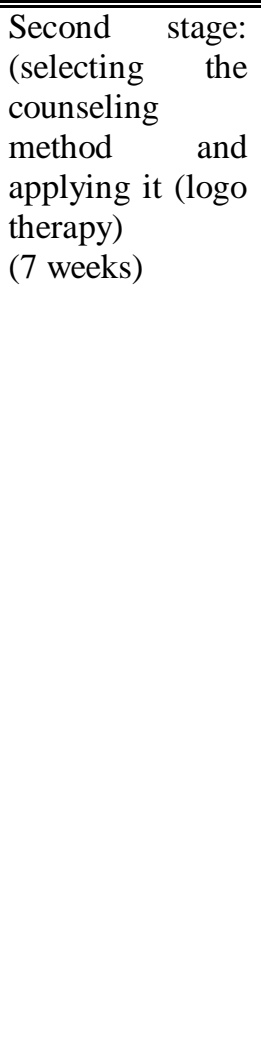 & $\begin{array}{l}\text { The researcher chooses at this stage the appropriate therapeutic } \\
\text { and counseling methods related to treating the slogan: } \\
\text { (identifying the obstacles to life, modifying the directions of the } \\
\text { treatment group, investing the positive meanings of life and } \\
\text { adapting to the meaning of life), through: } \\
\text { - Explaining the meaning of improving life, its aspects, and the } \\
\text { effects of lack of adaptation in life for children (Socratic } \\
\text { dialogue). } \\
\text { - Increasing the level of communication between deaf blind } \\
\text { children and their families, and encouraging the child to } \\
\text { express himself and his opinion, which leads to an increase } \\
\text { in his ability to interact with others inside or outside the } \\
\text { family. } \\
\text { Encouraging the child's family by discussing each child's } \\
\text { goal in life and identifying the positive meaning of life. } \\
\text { Helping them discover themselves by discussing the } \\
\text { strengths and weaknesses of each child, helping them to } \\
\text { accept themselves and bear tensions, while eliminating } \\
\text { blame and supporting self-confidence. } \\
\text { Discussing how the child spends his time with some } \\
\text { guidelines regarding the use of free time through the } \\
\text { schedule of various hobbies and preferences of everyone. } \\
\text { - Encouraging children to practice hobbies, sports and } \\
\text { life activities to get out of the isolation caused by } \\
\text { disability, by visiting centers interested in developing } \\
\text { the skills of deaf-blind children. }\end{array}$ \\
\hline
\end{tabular}




\begin{tabular}{||l||l||}
\hline $\begin{array}{l}\text { Third stage } \\
\text { (Results } \\
\text { evaluation) } \\
\text { (one week) }\end{array}$ & $\begin{array}{l}\text { Through re- application of the scale of improving meaning of life } \\
\text { among deaf blind children to verify the effectiveness of the } \\
\text { counseling program according to the achievement of counseling } \\
\text { objectives, client's feeling of satisfaction and happiness and better } \\
\text { change. }\end{array}$ \\
\hline \hline $\begin{array}{l}\text { Forth stage: } \\
\text { (Concluding the } \\
\text { counseling } \\
\text { process) } \\
\text { (one week) }\end{array}$ & $\begin{array}{l}\text { Preparing to conclude the professional relationship } \\
\text { (counseling). } \\
\text { Increasing time span between meetings. }\end{array}$ \\
\hline $\begin{array}{l}\text { Making sure that the objectives are achieved, as well as the } \\
\text { general feeling of satisfaction. }\end{array}$ \\
\hline $\begin{array}{l}\text { Fifth stage: } \\
\text { (Counseling } \\
\text { follow up) } \\
\text { (one week) }\end{array}$ & $-\begin{array}{l}\text { Making sure that the deaf blind child is improving. } \\
\text { Identifying the improvement rate and client's benefitting } \\
\text { from the counseling experience. }\end{array}$ \\
\hline
\end{tabular}

Fifth: counseling program strategies:

a. Stopping over thinking strategy: this strategy counters over thinking about one's self, constant self- observation and selfanalysis. This strategy is applied through helping the family to discuss the deaf blind child to encourage him/ her to think about him/ herself to identify their strengths and move forward.

b. Externally contradicting target: encouraging the individual to do or want things he/ she fears, through encouraging the deaf blind child to identify his/ her weaknesses and fears to deal with them. Both strategies depend on two main features of humans; human's ability to transcend and to detach from one's self.

Sixth: techniques used in the counseling program:

1. Socratic dialogue: to teach individuals how to manage their lives through dialogue that makes children create a new vision about their symptoms. To discover meaning in life through selfreflection, self-discovery, choice, uniqueness, responsibility and self-transcendence.

2. Attitude Adjustment: An individual can overcome his problems through his attitude towards such problems, by making a positive change in the customer's attitude towards oneself, conditions and obstacles and thus helping him to overcome the problems and adapt to the unsolvable. (inability).

3. Logo Analysis: Analyzing children's experiences to find new meaningful resources. Through the development of such experiences, we reach new experiences that reveal the new vision of the purpose of life. 
4. Compensatory self-improvement: it aims to increase the individual's sense of the possibilities available in other aspects of life that may appear either temporary or permanent as fixed and immutable inputs; Thus making the individual accept such aspects as they are and start searching for other aspects of life that have not been used enough to invest the energy wasted in pain and discover new life potentials for growth and overcoming the difficulties of disability.

Seventh: the programs factors of success: social worker and head of the center's cooperation and the development of a positive counseling relation between the researcher and the families, as well as families' positivity in applying the counseling program and achieving its goals.

Eighth: counseling program evaluation: the program is evaluated twice. Once during the execution through verifying that it is going as planned through observation and recording, and parents' desire to cooperate, participate and discuss; and one more time, in order to measure the outcome of the intervention using the counseling program, through the reapplication of the scale of life meaning improvement on deaf bind children via their families.

\section{Methodology}

According to the type of the research, the researcher deployed the pre-experimental approach based on pre- post measure of one experimental group. The pre and post measures of the group are compared, and the difference is then attributed to the intervention program. So, the effectiveness of the program is defined through the change in the group. The study population consisted of 33 deaf-blind children from the Alexandria Child Care Center and 10 partially blind male and female children were selected from an objective organized sample, ranging in age from 9-12 years, for the purpose and the objectives of study (according to sampling), whose families visit the center on regular basis. The children' parents agreed on applying the program. This center was selected for the availability of the sample and place for therapy meetings and for management and social workers' interest. The study deployed a life improvement scale, prepared by the researcher, who set its main aspects, according to the research concepts. These aspects are; first aspect: the goal of life, items 1 to 12, second aspect accommodation with life items 13 to 34 and the third aspect life satisfaction items 35 to 46. Each item has three responses: "yes" (3 points) highest measure, "sometimes" (2 points) medium measure and finally "no" (1 point) the least measure. 
The scale included 46 items distributed among the three aspects: for the highest measure 138 points, medium measure 92 points and the least measure 46 points. Scale validity: the researcher introduced the scale to 10 professors in social work to evaluate its items, in terms of form and relevance to the subject of study. Accordingly, the researcher rephrased some items and cancelled some items (at $\mathrm{p}=/>$ $80 \%$ ). Internal validity $=$ square root of the scale stability $0.93 \mathrm{~V}=0.97$; thus, proving high validity of the scale. Scale stability: the researcher applied re- testing method with 10 families of the deaf blind children, and retested it once again in 15 days, $\mathrm{p}=0.96$. The correlation was statistically significant.

\section{Results:}

First: the study results related to sample's characteristics showed that the causes of deafness and blindness were congenital, and they suffered partial deafness and blindness. $50 \%$ of the sample members were male and $50 \%$ were female children a certain factor deliberately chosen by the researcher in order to compare them on the scale of improving the meaning of life among deaf blind children. $50 \%$ of the children were at the age 11- 12 years, $30 \%$ were 10 - 11 years of age and $20 \%$ were at the age group from 9- 10 years. Therefore, the sample in general was from the stage of late childhood, in accordance with the sample selection term of 9- 12 years.

Table 1:Shows the difference of average measures of the pre- post scale on the aspect of " $g o a l$ of life for deaf blind children's= 10

\begin{tabular}{|c|c|c|c|c|c|}
\hline \multirow{2}{*}{ Variable } & \multicolumn{2}{|c|}{ Pre- measure } & \multicolumn{2}{|c|}{ Post- measure } & \multirow[b]{2}{*}{$\mathbf{T}$} \\
\hline & 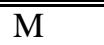 & 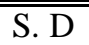 & $\bar{M}$ & 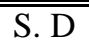 & \\
\hline First: goal of life & 14.70 & 0.95 & 33.80 & 0.92 & 60.738** \\
\hline
\end{tabular}

Tabulated $\mathrm{t}$ at $0.05=2.262$, tabulated $\mathrm{t}$ at $0.01=3.25 *$ significant at 0.05 , and $* *$ significant at $-0.01$

The previous table shows very significant differrences between the average pre and post measures of the experimental group on the aspect of the goal of life favoring the post measure as the values were 14.70 and 33.80 respectively. Calculated $t$ was $60.738 * *>$ tabulated $t$ 3.25 at 0.01 , between the average pre and post measures of the experimental group, thus referring to the effectiveness of the family counseling program to determine the goal of life among the deaf blind children. 


\begin{tabular}{|lc||}
\hline Egyptian Journal of Social Work (EJSW) & http://ejsw.journals.ekb.eg \\
ISSN: 2356-9204 & Vol 12, Issue 1, June 2021 \\
\hline \hline
\end{tabular}

Table 2: shows the difference of average measures of the pre- post scaleon the aspect of "life satisfaction for deaf blind children' $s=10$

\begin{tabular}{||l||l|l|l|l||l||}
\hline \multirow{2}{*}{ Variable } & \multicolumn{2}{|l||}{ Pre- measure } & \multicolumn{2}{|l|}{ Post- measure } & \multirow{2}{*}{ T } \\
\cline { 2 - 5 } & M & S. D & M & S. D & T \\
\hline \hline Second: life satisfaction & 15.0 & 1.70 & 34.20 & 0.79 & $30.528^{* *}$ \\
\hline
\end{tabular}

Tabulated $\mathrm{t}$ at $0.05=2.262$, tabulated $\mathrm{t}$ at $0.01=3.25 *$ significant at 0.05 , and $* *$ significant at 0.01

The previous table shows that there are highly significant differences between the average pre and post measures of the experimental group on the aspect of life satisfaction favoring the post measure, as the values were 15 and 34.2 respectively and the calculated $t$ was $30.528 * *>$ tabulated $t$ (3.25)at 0.01 between the pre and post measure, thus referring to the effectiveness of the family counseling program in achieving life satisfaction for deaf blind children.

Table 3: Shows the difference of average measures of the pre- post scale on the aspect of "the ability to accommodate of deaf blind children's $=10$

\begin{tabular}{|c|c|c|c|c|c|}
\hline \multirow{2}{*}{ Variable } & \multicolumn{2}{|c|}{ Pre- measure } & \multicolumn{2}{|c|}{ Post- measure } & \multirow[b]{2}{*}{$\mathbf{T}$} \\
\hline & 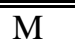 & 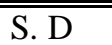 & $\overline{\bar{M}}$ & $\overline{~ S . ~ D ~}$ & \\
\hline Third: the ability to accommodate & 28.7 & 1.34 & 61.30 & 1.57 & $47.496^{* *}$ \\
\hline
\end{tabular}

Tabulated $\mathrm{t}$ at $0.05=2.262$, tabulated $\mathrm{t}$ at $0.01=3.25 *$ significant at 0.05 , and $* *$ significant at $-0.01$

The previous table shows that there are highly significant differences between the average pre and post measures of the experimental group on the aspect of the ability to accommodate favoring the post measure, as the values were 28.7 and 61.30 respectively and the calculated $t$ was $47.496^{* *}>$ tabulated $t(3.25)$ at 0.01 between the pre and post measure, thus referring to the effectiveness of the family counseling program in achieving the ability to accommodate for deaf blind children.

Table 4: shows the difference of average measures of the pre- post scale on the aspect of "meaning of life for deaf blind children's $=10$

\begin{tabular}{||l||l|l|l|l||l||}
\hline \multirow{2}{*}{ Variable } & \multicolumn{2}{|l||}{ Pre- measure } & \multicolumn{2}{|l||}{ Post- measure } & \multirow{2}{*}{ T. D } \\
\cline { 2 - 5 } & M & M & S. D & T \\
\hline \hline $\begin{array}{l}\text { Life meaning for deaf blind } \\
\text { children }\end{array}$ & 58.40 & 2.88 & 129.3 & 1.89 & $66.307^{* *}$ \\
\hline
\end{tabular}

Tabulated $t$ at $0.05=2.262$, tabulated $t$ at $0.01=3.25 *$ significant at 0.05 , and $* *$ significant at -0.01

The previous table shows that there are highly significant differences between the average pre and post measures of the experimental group on the aspect of meaning of life favoring the post 


\begin{tabular}{|lc||}
\hline Egyptian Journal of Social Work (EJSW) & http://ejsw.journals.ekb.eg \\
ISSN: 2356-9204 & Vol 12, Issue 1, June 2021 \\
\hline \hline
\end{tabular}

measure, as the values were 58.40 and 129.3 respectively and the calculated $\mathrm{t}$ was $66.307^{* *}>$ tabulated $\mathrm{t}(3.25)$ at 0.01 between the pre and post measure, thus referring to the effectiveness of the family counseling program in improving the meaning of life for deaf blind children.

Table 5: Shows the difference of average measures of the pre scale of female and male deaf blind children on the scale of meaning of life

\begin{tabular}{|c|c|c|c|c|c|}
\hline \multirow{3}{*}{ Variables } & \multicolumn{4}{|c|}{ Gender } & \multirow{3}{*}{$\mathbf{T}$} \\
\hline & \multicolumn{2}{|c|}{ Male $n=5$} & \multicolumn{2}{|c|}{ Female $n=5$} & \\
\hline & $\mathbf{M}$ & S. D & $\mathbf{M}$ & S. D & \\
\hline First:goal of life & 14.6 & 1.14 & 14.8 & 0.84 & 0.316 \\
\hline Second: life satisfaction & 28.60 & 1.52 & 28.8 & 1.30 & 0.224 \\
\hline $\begin{array}{l}\text { Third: the ability to } \\
\text { accommodate }\end{array}$ & 14.80 & 1.30 & 15.20 & 2.17 & 0.354 \\
\hline Total score & "58.0 & 2.83 & 58.80 & 3.19 & (419 \\
\hline
\end{tabular}

Tabulated $\mathrm{t}$ at $0.05=2.31$, tabulated $\mathrm{t}$ at $0.01=3.36$

The previous table shows that there are no differences between the average pre measures of the male and female deaf blind children in the experimental group on the scale of meaning of life, as the value of the calculated $t$ was smaller than the tabulated $t$ at 0.05 , thus referring to the lack of differences between the male and female respondents on the meaning of life scale with its three aspects; goal of life, life satisfaction and the ability to accommodate in the post measure.

Table 6: Shows the difference of average measures of the post scale of female and male deaf blind children on the scale of meaning of life

\begin{tabular}{|c|c|c|c|c|c|}
\hline \multirow{3}{*}{ Variables } & \multicolumn{4}{|c|}{ Gender } & \multirow{3}{*}{$\mathbf{T}$} \\
\hline & \multicolumn{2}{|c|}{ Male $n=5$} & \multicolumn{2}{|c|}{ Female $n=5$} & \\
\hline & 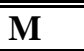 & S. D & $\mathbf{M}$ & S. D & \\
\hline First: goal of life & 33.4 & 0.89 & 34.20 & 0.84 & 1.461 \\
\hline Second: life satisfaction & 60.2 & 1.30 & 62.40 & 0.89 & 3.111* \\
\hline Third: the ability to accommodate & 34.4 & 0.89 & 34.0 & 0.71 & 0.784 \\
\hline Total score & 128. & 1.22 & 130.6 & 1.52 & $2.982 *$ \\
\hline
\end{tabular}

Tabulated $\mathrm{t}$ at $0.05=2.31$, tabulated $\mathrm{t}$ at $0.01=3.36$, * significant at $0.05, * *$ significant at 0.01

The previous table shows that there are differences between the average post measures of the male and female deaf blind children in the experimental group on the scale of meaning of life, as the value of the calculated $\mathrm{t}$ was larger than the tabulated $\mathrm{t}$ at 0.05 , and the difference were significant on the aspect of life satisfaction and nonsignificant on the aspects of the goal of life and the ability to accommodate, thus referring to the effectiveness of the family counseling program in improving the meaning of life on the aspect of 
life satisfaction for female respondents more than the male ones, which is confirmed by the following figure.

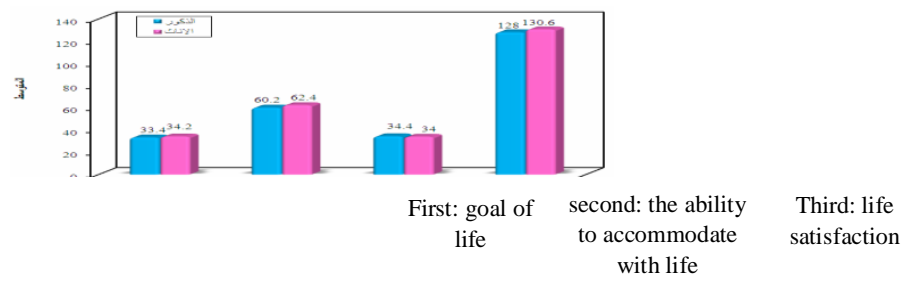

Figure 1: Differences between male and female children on the three aspects

\section{Discussion:}

The results of the study confirmed the validity of the first hypothesis of the study, as it proved the effectiveness of the family counseling program in improving the meaning of life for deaf-blind children, as the results confirmed the existence of statistically significant differences between the average of the previous and subsequent measurements of the experimental group on the meaning of life scale of deaf-blind children in favor of the dimensional scale. The results of the study agree with those of: Frederickson and Turner (2003),Kyzar (2010), Gaspar et al. (2017), (Kyzar et al., 2018), Wolsey (2017), Sayed (2015), Ezzat (2010)and Abdul Hafith (2008). Many studies have found the effectiveness of a training program to develop daily life skills for the deaf-blind children. Such studies emphasized the increased ability to perform daily life skills; the ability to communicate. Furthermore, they demonstrated that the treatment and its various techniques helps to discover the meaning of life and support the will to live effectively and to attain the quality of life and psychological comfort. This reflects a normal personality. The treatment modifies negative emotions into positive emotions. This modification helps the deaf-blind children to experience positive experiences, which contribute to the development of personality .It also helps reduce stress and suffering; and improves the quality of life. Such improvement can be achieved through: the importance of emphasizing self-development; discovering strengths in personality and developing it; supporting future goals and hopes; supporting positive meanings and striving to achieve them., These positive meanings increase positive feelings and emphasize that achieving personal identity requires achieving the meaning that represents The essential component of personality. Thus, positive meanings and satisfaction help achieve quality of life. Learning to treat with 
meaning represents a preventive aspect and plays a positive role in achieving positive mental health.

The results of the study indicated that the study cases have become able to define life goals, such as their ability to define tasks and accomplish their work, and to develop plans for a better future, as well as developing their capabilities to make decisions and strive to achieve them ,continuous self-development and ownership, understanding. of the time management skills required for success. The study results were consistent with those of White (2014)(Kyzar et al., (2018).

She also indicated that the study cases gained a sense of satisfaction with life and participation in tasks and programs aimed at developing independent living skills, forming good relationships with family members, visiting relatives, forming friendships and social networks. These results are consistent with those of Manga and Masuku (2020), Bruce et al. (2020), Roy et al. (2019).

The results also confirmed the children's ability to adapt in favor of telemetry. This indicates that the study cases became able to feel optimism, hope in life, confidence, impulse control, self-defense, and knowledge of civil rights. Furthermore, the practice of religious rituals regularly. These results are consistent with those of Preisler (2005), White (2014).

The study also suggested the validity of the fourth hypothesis of the study as the results showed differences in the average pre and post measures of male and female deaf blind children on the scale of meaning of life favoring the post measure of the female children on the aspect of life satisfaction, thus referring to the effectiveness of the family counseling program in improving meaning of life on the aspect of life satisfaction for female children more than male ones.

Conclusion:1- Increase the various forms of social, educational, sports, psychological and physical care provided to the deaf-blind, and work to develop their skills and meet their continuous needs.2Helping the families of deaf-blind children and providing them with continuous education, in terms of means of confronting the issues of their children, in order to become more in tune with society and more capable of social interaction.3- Activating the role of social service in care homes for deaf-blind children and their families.

Suggestions for future research:1- Deaf bind youth social empowerment mechanisms.2- Evaluating the social workers' roles in the deaf blind children care centers. 


\section{References:}

Abdul Hafith, S. (2008). Applying the Scandinavian Approach in improving the quality of life of deaf blind people, the International Sixth Conference: Qualifying the Handicapped: monitoring the reality and foreseeing the future: Educational Studies Teaching assistant, Cairo University.

Abu Ghazala, S. (2007). The Effectiveness of logo counseling in reducing the identity crisis and improving the positive meaning of life among university students. Cairo: Ain Shams University.

Abyadh, M.H. (2010). The Scale of Meaning of Life among Youth. Journal of Faculty of Education, Ain Shams University, 3(43), 799- 820.

Al- Khateeb, J.M.S. (1997). Hearing Disability. Jordan: National Library department.

Al-jabr, I.A.A. (2015). The reality of services provided for the deaf blind people from the point of viewof mothers in Kingdom of Saudi Arabia. International Specialized Educational Journal, 1, 336- 363.

Al-Utaiby, B.N., \& Sarttawy, Z.A. (2012). Supportive services needed for children of multiple disability and their families and their extent of availability from their parents and teachers' point of view. King Saud University Journal for educational sciences and Islamic studies, 1(24), 125- 158.

Aly, A.H.M. (2010). Psychological Guidance for Exceptional people and their families. Cairo: Teiba for Publishing and distribution.

Bruce, S., et al. (2020). Conceptual Paper for Re-Validating the Teacher of Deafblind and Intervener Competencies. Visual Impairments and Deafblind Education Quarterly, 65(1), 65-74.

Dammeyer, J. (2012). Identification of congenital Deafblindess. British journal of visual impairment, 30(2), 101-107.

Deaf-Blindness, N.C.o. (2018). The 2017 national child count of children and youth who are deaf-blind. New York: National Center on Deaf-Blindness.

Ezzat, A. (2010). Developing the creative thinking among deaf blind children using the principles of the Scandinavian approach, scientific conference: discovering and supporting the talented between reality and hoped situation (Thesis). Faculty of Education, Banha University.

Fathy, A. (2006). The effectiveness of logo therapy in reducing the identity crisis and achieving the positive meaning of life among visually disabled teenagers (Unpublished $\mathrm{PhD}$ Thesis). Faculty of Education, Suhaj, South of Valley University.

Frankl, V. (1982). A man seeking meaning: introduction to logo therapy and self- transcendence. Translated by: Talaat Mansour. Kuwait: Qalam Press.

Frankl, V. (1990). The Will of Meaning. New York: Penguin Books. 
Frederickson, N., \& Turner, J. (2003). Utilizing the Classroom Peer Group to Address Children's Social Needs An Evaluation of the Circle of Friends Intervention Approach. The Journal of Special Education, 36(4), 234-245. doi:10.1177/002246690303600404.

Gaspar, T., Rebelo, A., \& Dijk, J. (2017). An Interdisciplinary Approach of Deaf blindness. Asian Journal of Multidisciplinary Studies, 5, 2321-8819.

Hamidi, S., Yetkin, A., \& Yatkin, Y. (2010). The Meaning of Life: Health, Disease, and the Naturopathy. Journal of Psychology and Counselling, 2(1), 9-16.

Helen Keller National Center for Deaf-Blind Youths \& Adults (HKNC). (2015). Retrieved from https://www.helenkeller.org/hknc. [Accessed in: Feb, 2021]

Herbster, H. (2015). Special education eligibility and the category of deafblindness:Examining the perspectives of case coordinators (Doctoral Thesis). Ohio State University.

Ingraham, C.I. (2007). Transition Planning for Students Who are Deafblind Knoxville. TN: PEPNET-South.

Jaiswal, A., Aldersey, H., Wittich, W., Mirza, M., \& Finlayson, M. (2018). Participation experiences of people with deafblindness or dual sensory loss: A scoping review of global deafblind literature. PloS one, 13(9), e0203772. doi:10.1371/journal.pone.0203772.

Janssen, M.J., Riksen-Walraven, J.M., \& van Dijk, J.P.M. (2002). Enhancing the Quality of Interaction Between Deafblind Children and Their Educators. Journal of Developmental and Physical Disabilities, 14(1), 87-109. doi:10.1023/A:1013583312920.

Kyzar, K. (2010). The relationship of perceptions of service and support adequacy to family quality of life for families of children with deaf blindness (PhD Thesis). University of Kansas, Kansas, United States of America.

Kyzar, K., Brady, S., Summers, J.A., \& Turnbull, A. (2018). Family Quality of Life and Partnership for Families of Students With DeafBlindness. Remedial and Special Education, 41(1), 50-62. doi:10.1177/0741932518781946.

MacDonnall, M., Crudden, A., LeJeune, B.J., \& Stewerson, A. (2014). Availability of Mental Health Services from State Mental Health Agencies for Individuals who are Deaf-Blind: The National Research \& Training Center on Blindness \& Low Vision Mississippi State University.

Manga, T., \& Masuku, K.P. (2020). Challenges of teaching the deaf-blind learner in an education setting in Johannesburg: Experiences of educators and assistant educators. The South African journal of communication disorders, 67(1), e1-e7. doi:10.4102/sajcd.v67i1.649. 
McCormick, M. (2015). New to deafblindness? Five tips for administrators. USA: Texas School for the Blind and Visually Impaired.

Muller, E. (2006). Deaf-blind child counts: Issues and challenges. Alexandria, VA: Project Forum at NASDSE.

Nations International Children's Emergency Fund [UNICEF]. (2014). Child disability data. USA: UNICEF.

Nordic staff training center [NUD]. (2005). Nordic definition for Deafblindness. Alborg, Denmark: NUD.

Preisler, G. (2005). Development of Communication in Deafblind Children. Scandinavian Journal of Disability Research, 7, 41-62. doi:10.1080/15017410510032145.

Purvis, B., \& Schalock, M.D. (2014). Using evidence-based strategies and technical assistance to improve identification of infants and toddlers with combined vision and hearing loss. Visual Impairment and Deafblind Education Quarterly, 59(5), 20-24.

Roy, A., McVillly, K., \& Crisp, B. (2019). Working with Deafblind people to develop a good practice approach. Journal of Social Work, 21, 146801731986021. doi:10.1177/1468017319860216.

Sameer , A.G. (2007). The Effectiveness of logo counseling in reducingthe identity crisis and improving the positive meaning of life among university students. Cairo: Ain Shams University.

Sayed, Z.A. (2015). The effectiveness of training program in developing the deaf blind children skills (Master Thesis). Girls Faculty of Arts.

Simcock, P., \& Manthorpe, J. (2013). Deafblind and Neglected or Deafblindness Neglected? Revisiting the Case of Beverley Lewis. British Journal of Social Work, 44, 1-33. doi:10.1093/bjsw/bct088.

Sukontharungsee, S., Bourquin, E., \& Poonpit, M. (2006). A First Look at Children and Youths Who Are Deaf-Blind in the Kingdom of Thailand. Journal of Visual Impairment \& Blindness, 100, 557562. doi:10.1177/0145482X0610000907.

Trivette, C., \& Dunst, C. (2005, 01/01). Community-Based Parent Support Programs. Retrieved from http://www.childencyclopedia.com/parenting-skills/according-experts/communitybased-parent-support-programs. [Accessed in: Jan: 2021]

Tsuchiya, Y., \& Sugai, H. (2001). Initial Aspects of Children with Congenital Deaf Blindness. NISE Bulletin, 6, 9-16.

Turner, M.D., Baldwin, L., Kleinert, H.L., \& Farmer Kearns, J. (2000). The Relation of a Statewide Alternate Assessment for Students with Severe Disabilities to Other Measures of Instructional Effectiveness. The Journal of Special Education, 34(2), 69-76. doi:10.1177/002246690003400202.

Vector, F. (2004). Seeking the Meaning: Basics and applications of logo therapy. Translated by Iman Fawzy. Cairo: Zahraa Asharq Press. 


\begin{tabular}{|lc||}
\hline Egyptian Journal of Social Work (EJSW) & http://ejsw.journals.ekb.eg \\
ISSN: 2356-9204 & Vol 12, Issue 1, June 2021 \\
\hline
\end{tabular}

Vervloed, M.P., van Dijk, R.J., Knoors, H., \& van Dijk, J.P. (2006). Interaction between the teacher and the congenitally deafblind child. American annals of the deaf, 151(3), 336-344. doi:10.1353/aad.2006.0040.

White, F. (2014). Communication skills and quality of life aspects for the deafblind child: an investigation of communication partner perception. UK: Cardiff Metropolitan University.

Wolford, M. (2016). A school psychologist's guide to deafblindness: Identifying \& supporting students with combined hearing-vision loss. Dublin, OH: Ohio Center for Deafblind Educafion.

Wolsey, J.A. (2017). Perspectives and Experiences of DeafBlind College Students. The Qualitative Report, 22(8), 2066-2089.

World Health Organization [WHO]. (2017). World Report on Disability. Geneva: WHO. 
